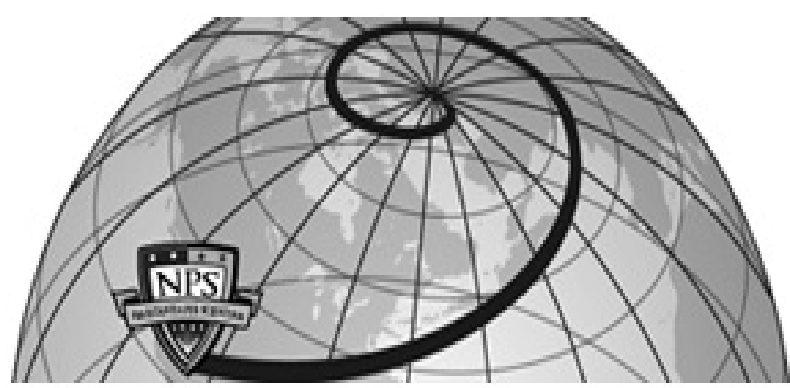

Calhoun: The NPS Institutional Archive DSpace Repository

\title{
Policymakers and Intelligence Reform in the
} New Democracies

Matei, Florina Cristiana; Bruneau, Thomas C.

International Journal of Intelligence and Counter Intelligence, Volume 24, Number 4, pp. 656691,2011

https://hdl.handle.net/10945/43280

This publication is a work of the U.S. Government as defined in Title 17, United States Code, Section 101. Copyright protection is not available for this work in the United States.

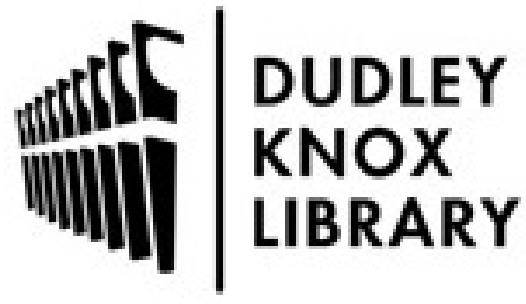

http://www.nps.edu/library
Calhoun is the Naval Postgraduate School's public access digital repository for research materials and institutional publications created by the NPS community. Calhoun is named for Professor of Mathematics Guy K. Calhoun, NPS's first appointed -- and published -- scholarly author.

Dudley Knox Library / Naval Postgraduate School 411 Dyer Road / 1 University Circle Monterey, California USA 93943 


\section{FLORINA CRISTIANA MATEI and THOMAS C. BRUNEAU \\ Policymakers and Intelligence Reform in the New Democracies}

In all democratic systems, intelligence reform is a "Gordian knot" that incessantly tests decisionmakers. The onus is on them to develop and maintain intelligence systems that protect democracy and are democratically accountable, while, at the same time, engage in secret

Florina Cristiana (Cris) Matei is a Lecturer at the Center for Civil-Military Relations (CCMR) at the United States Naval Postgraduate School (NPS), Monterey, California, which she joined in 2003 as a Research Associate. Holder of a B.S. in Physics (Nuclear Interactions and Elementary Particles) from the University of Bucharest, Romania, she received her M.A. in International Security Affairs and Civil-Military Relations from the NPS. Prior to joining the NPS, Ms. Matei worked for the Romanian Ministry of Defense as a civilian subject matter expert on Eastern Europe and European/Euroatlantic Security Organizations.

Dr. Thomas C. Bruneau is Distinguished Professor of National Security Affairs at the Naval Postgraduate School, where he has taught since 1987. He was Chairman of the National Security Affairs Department from 1989 to 1995. From 2000 to 2004, he was Director of the NPS's Center for Civil-Military Relations. Previously, he taught Political Science at McGill University, Montreal, Canada. Dr. Bruneau received his B.A. from the California State University at San Jose, and his M.A. and Ph.D. from the University of California at Berkeley. He was a Fulbright Scholar in India in 1962-1963 and in Brazil in 1985-1986. A specialist on Portugal, Brazil, and Latin America, he has published more than a dozen books in English and Portuguese. 
operations. This challenge has no clear solution. As experts at the Geneva Centre for the Democratic Control of Armed Forces (DCAF) put it, "the nature of intelligence is such that the balance between secrecy and democracy will always be a delicate one to strike." "In well-established democracies, policymakers have developed mechanisms to tackle the "democracy-intelligence" dilemma, yet these mechanisms are relentlessly being revised and reworked. In new democracies, however, decisionmakers must create these mechanisms from ground zero, and do not always succeed in balancing effectiveness with transparency. In those that do succeed, decisionmakers face numerous challenges, yet they may, after long and protracted endeavors, eventually manage to accommodate effectiveness and transparency. Both interest and willingness (whether self-initiated or due to outside pressure and/or incentives) on the part of policymakers are paramount in successful intelligence reform.

Here we analyze the experiences of seven developing democracies: Brazil, Argentina, Peru, Poland, Romania, Spain, and Russia. ${ }^{2}$ In all but one, policymakers have succeeded in institutionalizing intelligence agencies that are either transparent or effective, or both. In stark contrast, in the seventh country, Russia, policymakers have not been interested in democratic consolidation, and while they invested in intelligence reform, they did so for personal gain, not for reasons of democratic consolidation.

\section{RELEVANCE}

Research and literature on intelligence in developing democracies are emerging yet still scarce. Although a rich literature is available on intelligence in the Western, long-established democracies, only a few studies have been done on intelligence in the newer democracies. For example, in five of the most widely used and recent anthologies or handbooks on intelligence, with a total of 161 chapters, only 22 deal with intelligence in countries that have made the transition from dictatorship to democracy. A very comprehensive bibliography on intelligence, titled "Intelligence and Policy-Making: A Bibliography," prepared and periodically updated by Greta Marlatt of the Naval Postgraduate School (NPS) library for teaching and research purposes, also reveals that, of the over five hundred books, reports, and documents listed, only some thirty deal with newer democracies. ${ }^{3}$ And the existing studies of intelligence in new democracies focus almost exclusively on democratic control, not on effectiveness. In our work with the Center for Civil-Military Relations (CCMR) and the National Security Affairs (NSA) Department within the NPS at Monterey, California, we learned that in many countries, policymakers, for various reasons, either do not care, or even if they do, do not know how to deal with intelligence reform. 
Even in more mature democracies, interest or expertise on how to deal with intelligence reform is often lacking. ${ }^{4}$

Moreover, in many new democracies, the polemic has developed about the term information versus intelligence (in Romania) and vice versa (in Portugal). In Romania, for example, the word "intelligence" refers strictly to "cleverness," and intelligence agencies have always been called "information agencies" or "secret services." Admittedly, in the twenty-first century and in a democratic society, agencies do more than gather information. From this perspective, Romanian intelligence practitioners and policymakers are currently endeavoring to introduce "intelligence" into the vocabulary. In Portugal, the term during the Salazar's nondemocratic regime was "intelligence," so that the currently acceptable term is "information." The reverse is true in Brazil, where the National Information Service has been replaced in the democracy by the Brazilian Intelligence Agency (ABIN).

The lack of interest and investment in striking a balance between effectiveness and transparency can result in either intelligence illegalities and abuses or a failure to protect national security and democratic values in the older as much as in the newer democracies (e.g., the United States, United Kingdom, Spain, India, etc.). Policymakers and intelligence professionals in developed democracies are increasingly encouraging cooperation with newer democracies so as to avert national and global security threats. Decisionmakers in the developed democracies must be confident that they can share information with compatible, capable, and accountable intelligence agencies from newer democracies.

This article seeks to improve the literature on intelligence reform in new democracies and to respond to the need for confidence in both the achievement of accountability and effectiveness.

\section{THE INTELLIGENCE FUNCTION AND THE ROLE OF POLICYMAKERS}

Intelligence ${ }^{5}$ is a three-tiered element of national security. It is (1) a Process by which certain types of information (e.g., security threats, strategic threat estimates, future capabilities projections, indication and warning) are required and requested, collected, analyzed, and disseminated to decision/ policymakers, and by which certain types of covert action are conceived and conducted; (2) an Organization, with units that execute the intelligence functions (process and product); and (3) a Product of these processes and organizations (e.g., analyses, intelligence estimates). The purpose of intelligence is to serve, inform, assist, and support policymakers' decisions, as well as to provide support to operations and other security organizations. Hence, intelligence entails both information and response. ${ }^{6}$ 
Intelligence is also a cycle (Figure 1) of various functions on behalf of national security policymakers, reflecting their needs, requirements, and benefits. Requirements are elements of the direction, planning, and guidance of the entire intelligence function and activity by decision- and policymakers such as the President, the Prime Minister, the National Security Council, the National Intelligence Board, various Ministries involved with national security, or other government institutions. Information and data are collected from secret and open sources, such as human, communication, imagery, and cyber. The raw information and data are selected, processed, and converted into a manageable format for the development of finished intelligence, including translation and decryption. Then, the fusion, production, and analysis takes place, which involves merger, combination, integration, examination, assessment, and analysis by the intelligence analysts of all processed and exploited data and information, as well as the preparation of varied intelligence products, generally based on the decisionmakers' requirements and preferences. The final product is disseminated to policymakers who will make decisions and draw policies, which may or may not start another cycle with additional requirements.

The uniqueness of the intelligence sector as compared to, for example, other branches of government is that its functions are centered in, and

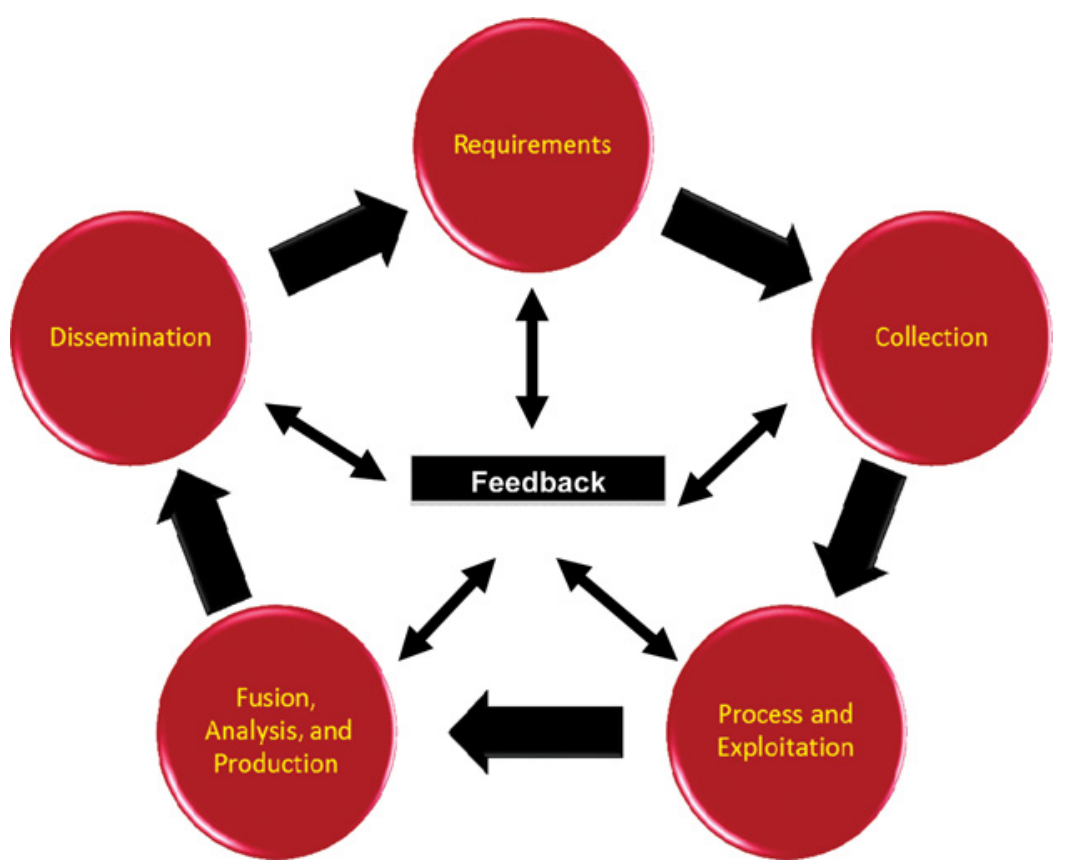

Figure 1. Intelligence Cycle. (Figure appears in color online.) 
intended for, the state, and are most often secret. The central tenets of intelligence are timeliness, accuracy, completeness, usability, and relevance. Informed policymakers need adequate information on known and unknown security risks, as well as reliable and usable analysis (sometimes tailor-built to the specific needs and requirements of a particular decisionmaker), on time or "at the right time." Without intelligence, policymakers cannot make informed decisions regarding national security and defense.

Policymakers are an integral part of the cycle: they are the "alpha" and "omega" of the intelligence function. They start the cycle through requirements and guidance and keep it working by providing feedback. They also end the cycle by taking relevant national security decisions and policies. As author Robert Kennedy has argued, "Art of Intelligence' begins not with analysis, but with judgments that lead to the selection of the information to be sought, permeates every phase of the intelligence process, and ends with judgments by key officials on how to use the information received." 7 Feedback and dialogue between intelligence producers and customers are cardinal. Policymakers need to make their needs clear to intelligence agencies, let the intelligence professionals know how accurate, useful, and tailored to their needs and requirements the product is, and convey any new guidance or adjustments to the intelligence cycle (including pointers on how to improve intelligence collection and/or analysis to better suit requirements). The bottom line is to prevent misdirection and waste of time and resources. As former President Bill Clinton's second national security adviser, Samuel R. "Sandy" Berger, put it when talking about the effectiveness of the intelligence process in the United States, "things happen when the number one person is in the room... When... he goes back...to his agency [and] shakes that agency for whatever it has." 8 Policymakers cannot surmise about the intentions of the adversary, traditional or not, without intelligence collection and analysis. Yet, as Robert Kennedy stated, "successful analyses depend in the first instance on effective management not just from within the IC, but also by the policymakers themselves." 9 On the same note, Mireille Radoi, a Romanian scholar specializing in intelligence, states that the performance of the intelligence contribution to national security is a function of the "producer-consumer" relationship. ${ }^{10}$ Nevertheless, although a cooperative and symbiotic ${ }^{11}$ relationship needs to exist between intelligence producers and consumers, the bottom line for the intelligence function is to serve policy without being or becoming politicized, or worse, without becoming the decisionmakers' political police, especially in the newer democracies. Finally, as Dr. Jennifer Sims, a former U.S. State Department official has noted, "a high-quality intelligence process 
balances investment and direction from decisionmakers with unbiased collection and analysis." 12

\section{WHY SHOULD POLICYMAKERS CARE ABOUT EFFECTIVE INTELLIGENCE?}

Democracies, old and new, need intelligence to fight security challenges and threats, and to follow global developments. In-depth information and knowledge are required to understand both the strategic context and potential security developments, including security risks and opportunities, as well as the actions, inactions, motivations, and strategies of existing and potential adversaries. They can also help predict how potential allies and partners could help confront these challenges, and are crucial in defining national interests, developing effective security policies and strategies, establishing adequate roles and missions for security forces, and elaborating doctrines and operations. ${ }^{13}$ They not only help avert national crises but are important in managing them effectively when they do arise. Thus decisionmaking uses information as a "shield" or "weapon" against national security threats. Only if policymakers are adequately informed about the current and future security context can they be expected to make suitable judgments in the realm of national security, defense, and foreign relations. ${ }^{14}$ Without effective intelligence as the first line of defense against any potential security risk or threat, these are impossible.

Democracies face myriad security risks and challenges, characterized by a high degree of uncertainty, unpredictability, and complexity, which imperil national security. Included are dangers to the rule of law and good governance, as well as to individual rights and liberties. Decisionmakers need to comprehend these matters in order to develop policies and directions that effectively avert, counter, and fight them. Today, such threats and challenges come less from organized, hierarchical state actors, and more from non-state, adaptable, network-centric groups and organizations which have progressively succeeded in altering the traditional geographic borders between countries, as well as between domestic and foreign threats. As the RAND Corporation's Deborah G. Barger asserts, "Globalization, the Internet, and the interconnected economy, once cited as forces for integration, peace, and stability, are also creating a world of extremes." 15 Such matters include traditional conflict (e.g., between Russia and Georgia in 2008), organized crime (e.g., post-Cold War networks of drug, arms, and human traffickers operating virtually throughout the globe, including South Eastern Europe and Latin America), terrorism (e.g., Argentina in 1992/1994, Romania in 2006), 
proliferation of weapons of mass destruction (WMD), and cyber attacks whereby electronic data, information, and knowledge are used as a weapon (e.g., Estonia 2007, Georgia 2008). In recent years, these security risks have clearly illustrated how instability or the specific ideologies and religious convictions of small groups of people, can impact the peace and security of a country, region, or the whole world.

Decisionmakers are required to fight such an unconventional phalanx, which jeopardizes not only state security, but endangers the very values of democracy. This nonaligned panoply of threats can rarely be disrupted by traditional military threat or nuclear deterrence, which some of the new democracies cannot even begin to afford. Taking the right decisions and drawing up suitable security policies to counter such threats depend, among other things, upon the quality of the preliminary work and the final product prepared by the intelligence agencies. The decisionmakers need feasible intelligence, assessments, and warning. And they must accept a certain amount of intelligence secrecy in the "the name of security.", Policymakers need, therefore, to be interested in having effective intelligence in order to protect national security and democracy. In a new democracy, effective intelligence is an even more necessary requirement. In virtually all nondemocratic regimes the intelligence apparatuses (whether political police or independent security states) were "effectively" serving the political class by collecting information, relentlessly monitoring — and frequently abusing and killing - citizens. Effectiveness in the democratic sense was not an issue during the nondemocratic regime period. After a regime change, the new agencies have tended ${ }^{17}$ to preserve the personnel of the nondemocratic intelligence apparatuses, so policymakers in the developing democracies need to ensure that the new agencies effectively serve the security needs of the democratic country, not of a minority sector.

Policymakers need effective intelligence for the following reasons: (1) to avoid strategic surprises to the national security, whereby intelligence anticipates and keeps track of current and potential security risks; (2) to acquire and capitalize on long-term expertise in defense and security matters, whereby intelligence agencies act as "libraries" for decisionmakers, providing a comprehensive database and pool of expertise on national security issues, as well as "information brokers," due to the abundance of available information, especially via open source, which requires rigorous verification by experts; (3) to get support in the overall policy process whereby intelligence agencies provide policymakers with tailored and timely intelligence; and (4) to ensure that the secrecy of information, needs, sources, and methods required by the intelligence function when protecting national security is safeguarded. ${ }^{18}$ 


\section{THE IMPORTANCE OF INTELLIGENCE TRANSPARENCY}

Nevertheless, championing only intelligence effectiveness may be dangerous to a democracy. Effectiveness usually depends on secrecy, which may feed abuse and insulate the agencies from any form of scrutiny-intrinsic or extrinsic. Since intelligence agencies have access to large amounts of information and knowledge regarding national security, and since the information flow is generally unidirectional (from intelligence to state and society), and sometimes uneven (intelligence agencies may withhold information), their "power" may rise, and they may refuse to serve policy, but instead pursue their own objectives. As a consequence, national security has become ever more dependent on highly effective intelligence (especially in fighting terrorism), and intelligence agencies have asked for increased powers and privileges. Because intelligence professionals and organizations regularly break laws abroad, they may willingly conflate "abroad" with "at home" and transgress there too. An additional danger is intelligence politicization, which can happen two ways: "down" (i.e., policymakers "dictate" to the intelligence professionals what product they want); and "up" (with intelligence professionals willingly providing policymakers with the product they know the decisionmakers want). Politicization leads to the misuse by the executive branch, for its own political ends, of intelligence agencies and their inherent special privileges. With consequences on both accountability and effectiveness. Characteristic of countries that transitioned from nondemocratic regimes to democracies is the fact that democratic consolidation takes time and can always regress as some factions may be interested in bringing back the nondemocratic regime: intelligence may help to do so. In addition, the legacy of the nondemocratic past and its misconduct (particularly in human rights violations for personal or political reasons/vendettas, not always connected to national security) may persist after the regime change, in that the retained personnel may perpetuate such methods or, even worse, teach the new group the old methods. The danger is that the intelligence agencies might either return as political police (with the politicians using them to deter and remove potential political adversaries, control aggressive investigative journalists, and deflect other possible opponents), or as independent security states, functioning for their own purposes. This possibility needs vigilance from policymakers in order to keep the intelligence services insulated from politics and political parties while serving the state and citizens, and thereby distancing them from their previous status.

Essentially, policymakers should become interested in intelligence transparency (including control and oversight) to not only prevent such wrongdoing as the misuse of the budget and human rights abuses such as 
illegal intrusive actions, but also to help improve intelligence effectiveness via feedback and recommendations.

\section{POLICYMAKERS AND THE DEMOCRATIC REFORM OF INTELLIGENCE}

Democracy calls for politically neutral, transparent, and accountable, yet effective, intelligence. So, how can policymakers in new democracies contribute to democratic reform of intelligence agencies? What should they do to balance the effectiveness of intelligence agencies with transparency, accountability, and citizens' liberty? Are there any challenges or obstacles that hinder their endeavors? How can these be overcome? When, in comparison with the reform of other state sectors, should they be involved in the democratic reform of intelligence? Can they do so without politicizing intelligence?

Democratic reform of intelligence involves a continuum of numerous intertwining steps and processes toward establishing an institutional framework whereby democratically elected civilians can control the intelligence agencies and at the same time maximize their potential for effectiveness. These should be acceptable to the population that votes for the politicians who have responsibility for establishing and controlling the institutions. ${ }^{19}$ To begin with, policymakers need to create new agencies or reorganize old ones. To avoid a concentration of power in the hands of one agency, the newly created agencies should balance foreign with domestic intelligence, military with civilian, and national defense with law enforcement. Decisions should also be made regarding to whom the intelligence product should be disseminated and on what basis. The creation of intelligence agencies needs to be closely followed by the crafting of clear and robust legal frameworks, and the updating of any obsolete legislation, in order to establish intelligence roles and missions in line with the functioning of intelligence in a democracy. Intelligence-related legislation should also stipulate methods of control, oversight, and accountability, as well as promote openness and transparency. The legal framework must develop from the new democratic structures and processes, and must endeavor to guarantee, in the realm of intelligence, the democratic values that they aspire to advance. In line with the previous two steps, decisionmakers should focus on helping to institutionalize the effectiveness of intelligence by ensuring competent political direction and guidance, as well as crafting and implementing security-related plans (meaning strategies and doctrines) by robust structures and processes such executive bodies as a National Security Council and appropriate Ministries. They should also encourage interagency and international coordination/cooperation, and allocate sufficient resources, consisting of the political capital, money, and personnel, to ensure that the services have 
sufficient equipment, trained forces, and other assets needed to implement their assigned roles and missions. In parallel, policymakers should seek to establish and strengthen institutions and mechanisms for the control and oversight of the intelligence services, to ensure that the agencies are doing the right thing, and are, at some level, accountable to the public. If failures are identified, the oversight mechanisms must be able to take action to avert future failures.

But democratic control and oversight should not violate the intelligence agencies' right of protecting their sources and methods and ongoing operations. Formal mechanisms of democratic control and oversight of intelligence agencies may include control by the executive (be it a president, prime minister, or NSC), the legislative branch through permanent or temporary committees, the judicial branch, as well as by internal control, through inspectors general. All should work together to provide "assurance of legality, proportionality and propriety" ${ }^{20}$ for intelligence personnel, activities, and resources. These mechanisms may be supported by other formal institutions that could provide oversight, such as Public Ministries, Ombudsman offices, and Courts of Audits. Besides the formal mechanisms, informal mechanisms of oversight by the civil society through nongovernmental organizations (NGOs), think tanks, academia, and the media, and lustration mechanisms, as well as international organizations dealing with human rights issues, can play a key role in overseeing intelligence, especially when formal mechanisms fall short. In newer democracies, decisionmakers should be involved in intelligence reform from the beginning to ensure the development of all these arenas.

\section{CHALLENGES TO POLICYMAKERS}

Policymakers face several challenges when attempting to undertake intelligence reform-some from the agencies, some from within themselves. Intelligence agencies most frequently attempt to resist democratic reform for a variety of ideological, political, and bureaucratic reasons. Intelligence officers also oppose reform because they mistrust the policymakers' expertise in intelligence, doubt their interest in national security, and consider too much outside involvement and scrutiny, as well as transparency, as jeopardizing their agencies' effectiveness. In addition, and as a characteristic of new democracies, the legacy of the past tends to linger years after the regime change. Newly created intelligence agencies may oppose democratic reform so as to prevent the loss of prerogatives they had during the nondemocratic regime, as well as to avoid any potential downsizing, vetting, and retrospective investigation of their past activities. Since many new intelligence agencies retain old personnel, their access to information, files, and records may be used to impede democratic 
reform. The policymakers themselves may lack interest in, or intentionally avoid, reforming intelligence. Other reforms may have top priority, those that may bring in more votes-such as health, education, and economic development - to the detriment of intelligence, which normally brings in no votes. The decisionmakers may also wish to be able to deny knowledge of illegal intelligence operations in order to avoid any possible suspicion that they tolerate unlawful activities and practices. Or, they may fear that the intelligence agencies may have some embarrassing information about them, or, as in the case of new democracies, wish to avoid suspicion of having been involved in earlier political police activities. Another reason could be their lack of interest in the actual democratic consolidation of the country; this would beget democratic regress and employment of strong intelligence agencies for their own personal gain. Policymakers generally lack knowledge and expertise on intelligence issues and intelligence reform. Even in the old democracies, where the debate between liberty and security has been around for years, policymakers still make mistakes and are unable to strike the proper balance between effectiveness and transparency. They fail to understand that intelligence has its limitations and may sometimes be wrong. As Columbia University professor Robert Jervis argues, "Unfortunately, not only will even the best intelligence services be wrong very often, but when they are true to the available evidence their reports are likely to be inconclusive, and when they are right they will often bring disturbing news. ${ }^{21}$ In new democracies, the lack of knowledge and expertise in intelligence is even more manifest because the new policymakers generally have no prior exposure to either what intelligence involves in a democracy or what avenues they need to follow for intelligence reform. Corruption is another challenge, whether within the agencies or within the executive and legislative branches of the government.

All these lead to, at a minimum, a "hands-off" attitude toward intelligence and intelligence reform by decision- and policymakers, or, at a maximum, to hasty or perfunctory reforms. Neither of these is satisfactory.

\section{Overcoming the Challenges}

Of all the previous challenges, interest in intelligence reform is the most demanding. An ignorance of intelligence can have grave policy and security consequences. What incentives do decisionmakers then have to reform intelligence? A first possible incentive is personal prestige and recognition. They may wish to remain in history as "pioneers" of opportune and/or successful intelligence reforms. ${ }^{22}$ Or, they may seek to secure for their country the role of regional hegemon, or, as with Brazil, as a contributor to PSO, and, in the newer democracies, to prevent a return to a nondemocratic past. A second possible incentive for 
decisionmakers is an awareness and understanding of security threats, as well as the importance of their own role in the cycle for successful security policies. As in Brazil they can learn of these on their own, or be prompted by an emerging or past security crisis/disaster, as, for example, the United States and Argentina, after terrorist attacks. A third possible incentive is the receipt of financial support and assistance from other countries. Related to this is an external drive, such as the membership requirements of various regional security cooperation agencies, notably NATO and the EU, along with pressure from domestic and international media and public opinion. Any combination of these potential incentives could interest decisionmakers in reforming intelligence.

With a certain amount of political will, whether motivated by outside incentives or personal reasons, policymakers can overcome challenges and achieve significant progress in the democratic reform of intelligence. They can improve democratic control capabilities and strengthen the effectiveness of intelligence work. Doing so involves developing additional principles and practices to boost the effectiveness of the intelligence agencies and strengthen the democratic nature of control and oversight through such avenues as: fostering an intelligence and security culture; raising public interest in intelligence and security matters; and increasing civilian expertise in intelligence by allowing access to unclassified literature, educating and training personnel in intelligence (jointly with foreign and domestic counterparts and representatives of civil society); capitalizing on the expertise of support staff; and generating a public debate on intelligence reform, and professional intelligence agencies, by open and rigorous recruitment, education and training, career planning, leadership, interagency cooperation, and investing in analysis (e.g., in critical and imaginative thinking). In all these, feedback is crucial. As previously mentioned, if failures occur, policymakers must help intelligence learn from past mistakes and improve.

\section{GLOBAL EXPERIENCES: SEVEN CASE STUDIES}

Original research is here offered on six countries where the issue of intelligence and/or intelligence reform has been addressed. Located in different regions of the world, they are at different stages of democratic transition or consolidation and confront different national security and defense challenges. Each is discussed with the intention of drawing lessons regarding the contribution, if any, of policymakers to intelligence reform, noting as well the obstacles to balancing intelligence effectiveness with transparency. ${ }^{23}$ These cases were selected as examples of reform, but in most countries, policymakers are unable to contribute to reform or are not at all interested in intelligence. 


\section{Brazil}

Brazil began its democratic reform of intelligence in 1990 with the inauguration of President Fernando Collor de Mello, who extinguished the SNI and the SISNI, considered the "evils" of the nondemocratic regime. This constituted the most critical and basic reform in the Brazilian intelligence system. Since the abolition of SNI, officers and officials from the Executive Branch - namely the President, the Secretariat for Institutional Security (GSI), other Ministers, Commanders of the Armed Forces, the Chief of General-Staff, as well as and members of the legislative chambers have strived to bring about a new intelligence system. Brazil now has, at least on paper, an extensive intelligence system, the Sistema Brasileiro de Inteligencia (SISBIN), composed of some twenty different organizations, either parts of various ministries or independent, including the Brazilian Intelligence Agency (Agencia Brasileira de Inteligencia-ABIN) ${ }^{24}$ created on the ruins of the SNI in 1999 as the central agency of the system (though it supposely operates under the coordination of the GSI). ${ }^{25}$ These organizations are both military and civilian including law enforcement, and conduct domestic and foreign intelligence. Policymakers established a legal framework that stipulates the intelligence agencies' roles and missions for safeguarding the Brazilian citizenry, and not only the state itself. The legislation also determines their relationship with policy - to serve policy but be politically neutral. The legal framework also provides for domestic interagency coordination and cooperation, whereby ABIN is the central agency of SISBIN, operating under the Institutional Security Secretariat of the Presidency of the Republic (GSI), as well as foreign cooperation and sharing. Also established were several mechanisms of democratic control and oversight of intelligence: (1) internal and agency control through the director of ABIN; (2) Executive control and oversight, through the Minister of the Secretariat of Institutional Security, assisted by an advisory board Chamber of Foreign Affairs and Defense (CREDEN) to monitor intelligence policy implementation, as well as through the GSI for all the intelligence agencies; (3) Legislative control and oversight, through the Joint Committee for the Control of Intelligence Activities (CCAI); and, (4) a Public Prosecutor's Office, as watchdog against misconduct of public or even private officials.

Brazil's post-authoritarian intelligence system has been the creation of civilian policymakers: a roundtable process involving the drafting of proposals and legislation for new intelligence agencies, review and debates by members of Congress, and approval by Congress. The incentives were personal for many of the proponents as they sought to avoid a return to the non-democratic past. The reformers have been interested and focused, 
at least until recently, only on strengthening the accountability, legality, and transparency of the intelligence community, and very little on its effectiveness. From the start, their main preoccupation was how to construct an agency that differed from the SNI in terms of structure, procedures, and orientation. Many questions had to be answered: Would one service deal with both foreign and security intelligence, or would creation of two separate agencies be preferable? How should intelligence officials be recruited and trained? What should be done with personnel from the authoritarian regime still working in the service? And, most important, how could the political establishment avoid the possibility of a secret service becoming a menace to democracy and society? Effectiveness, therefore, was not a high priority for the decisionmakers, whose understanding of the role of "effective" intelligence in a democracy was minimal. For many years these civilians saw intelligence as more a threat to democracy than a protector of the state and society. In addition, after the Cold War when the traditional "enemy" vanished, policymakers in Brazil, as in many other democracies, considered intelligence useless. Thus, the very new concern with intelligence effectiveness was prompted by their awareness of nontraditional threats such as extensive violence by organized crime in the cities of Rio de Janeiro and São Paulo, and potential threats to global sports events with large international participation which can make Brazil a target. Prestige was an additional incentive, due to awareness of the country's greater projection on the world stage as a result of its very successful and high-profile peacekeeping in Haiti.

For Brazil, balancing intelligence agencies' transparency with effectiveness has been a challenging process. First to be overcome was the legacy of its awful past experience with the SNI, which was a state within a state. Due to past abuses and human rights violations (which society still tends to associate with national security, defense, and intelligence), neither Brazilian society nor policymakers have been willing to support intelligence effectiveness. Second was the leaders' lack of knowledge. Development has been rather slow and drawn out due to political weakness and fecklessness in the executive branch between 1990 and 1995, and the slow emergence of interest in the issue of intelligence by members of the legislative branch.

More recently, policymakers have been implementing changes in the intelligence community and its oversight mechanisms. To foster a political culture that supports and respects intelligence, including better knowledge and understanding by civilians, and improving intelligence professionalism, the CCAI, especially when Severiano Alves became Chairman, has met with the intelligence community on a regular basis to discuss, among others, the IC's needs in terms of budget and recruitment issues, as well as to present envisaged IC-related legislative changes. Such initiatives were welcomed by IC. ${ }^{26}$ 
In February 2009, the President set up an inter-ministerial committee to debate the pace and outcomes of intelligence reform, come up with needed changes regarding intelligence activity, and draft the nation's first ever National Intelligence Policy (PNI) to clarify roles and missions and improve planning, guidance, and coordination, as well as provide avenues for checks and balances of intelligence activity. After debates within the Presidency and the National Defense Council (CDN), the PNI is now under CCAI review. Alves introduced a Project of Amendment to the Constitution (PEC), which, if approved, would include intelligence. It would authorize such constitutionally legitimated functions as specifying the IC's roles and missions in Brazil's national security, setting up interagency channels, and establishing clear prerogatives for the IC's management, while also strengthening control and oversight. A new legal framework for the IC might be worked out by the Executive, stipulating new mandates for several agencies and setting up subsystems of defense intelligence, criminal intelligence, financial intelligence, and strategic intelligence. These are to be coordinated, respectively, by the Ministries of Defense, Justice, Economy, and the GSI, which have otherwise encountered some resistance from within the IC. A draft law on the CCAI was initiated in 2008 , but has not yet been enacted. ${ }^{27}$

\section{Argentina}

Since December 1983, Argentina has strived to transform its intelligence community from being an instrument of the military dictatorship to an intelligence system that serves democracy. Argentina's National Intelligence System was created on the ruins of former non-democratic agencies, especially the former State Information Secretariat (SIDE) that had been established in 1956, and the national Intelligence Center (CNI) established in 1966. The current system consists of three agencies: the Secretariat of Intelligence (SI), as the main intelligence body; the National Directorate for Criminal Intelligence; and the National Directorate for Strategic Military Intelligence. These agencies are civilian and military, and conduct domestic (police/law enforcement), military, and foreign intelligence.

Argentina's situation reveals the interest and preoccupation of the civilians in the executive and legislative branches to curtail intelligence power and privileges as a consequence of the human rights abuses and transgressions committed during the non-democratic regime. Toward this end, civilian policymakers have channeled their efforts for reforming intelligence toward establishing and implementing democratic civilian control of the agencies, to the detriment of effectiveness. The changes affected the military intelligence, in that they involved considerable demilitarization, and limited powers of domestic intelligence, civilian control and oversight by the 
Executive and Congress, as well as new legislation regarding intelligence activities.

After setting up new agencies, the policymakers refined the legal framework to delineate the roles, responsibilities, and missions of the armed forces, intelligence, and police, set up interagency coordination avenues, and stipulated civilian control and oversight of the intelligence agencies. In parallel, a human rights policy was introduced during the administration of Raul Alfonsín (1983-1989), and trials of the leaders of the military juntas commenced in civilian courts. Democratic control and oversight were implemented by the Executive through the successive Presidents, who have been directly involved in monitoring intelligence activity and changes; the Congress, through a Joint Committee for the Oversight of Internal Security and Intelligence Activities and Agencies, established in 1993; and the Judicial branch, meaning the court system.

Despite continued interest in achieving intelligence transparency, reform has been less than perfect. An early challenge was the agencies' strong resistance. The civilian heads of the SIDE during the Alfonsin administration encountered tremendous opposition from within the armed forces and the military intelligence agency when attempting to civilianize it, which led to the resignation of one civilian director. The policymakers' lack of knowledge and expertise about intelligence also hampered reform. In April 1997, a Joint Committee for the Oversight of Internal Security and Intelligence Activities and Agencies was set up to provide the executive branch with findings regarding intelligence reform and activity. In an ensuing report, the Committee noted significant faults in the legal basis for intelligence, flawed interagency coordination, the absence of a national strategic intelligence plan, and limited regional/ international cooperation. Corruption and legacies of the past have also been problems, and more specifically, increases and spending of the secret budget, including the discretionary use of secret expenditures. Examples include the hijacking by Carlos Menem's administration (1989-1999) of public funds originally assigned by the Budget Law to secret expenses for paying extra salaries and the informal distribution of funds among public officials; alleged approval by Fernardo de la Rúa's administration (1999-2001) for using secret expenditures for payment of bribes to members of the Senate in 2000; continued tendencies to involve the military in domestic intelligence and security, for political versus national security reasons, including the November 1998 surveillance by the Air Force's intelligence agents of journalists and NGOs, and the Army's illegal intelligence activities against political parties, trade unions, and university groups in 2000. These actions demonstrated a lack of progress in the transparency and accountability of intelligence, let alone in its effectiveness. 
The concern with effectiveness happened only after Argentina became a target of two terrorist attacks in the early 1990s - the bombing of the Embassy of Israel in 1992, and of the Asociación Mutual Israelita Argentina (AMIA), a Jewish community center building, in 1994, with a total loss of life of 114 - when the government began to realize the change of the post-Cold War security environment. The two terrorist bombings in Buenos Aires in the early 1990s demonstrated the intelligence agencies' lack of capability to avert security threats and risks, and to inform policymakers in due time. To boost the effectiveness and professionalism of the intelligence community, a considerable number of personnel were dismissed while qualified personnel were hired, and the secret budget was reduced. Over time, interagency coordination as well as regional intelligence cooperation have been improved. Judicial access to SIDE secret accounts was enabled. The events of 11 September $2001(9 / 11)$ made policymakers aware of the need for effective intelligence, particularly from the perspective of international and regional cooperation. This led to Argentina's more assertive involvement in various regional cooperation initiatives, including the Tri-border Tripartite Command, the Mercado Comŭn del Sur (Common Market of the South) (MERCOSUR), and the "3 + 1 Regional Cooperation Mechanism." In addition, to boost intelligence community effectiveness and transparency, a National Intelligence Law was enacted in December 2001. The law granted greater authority to the President vis-à-vis the direction, guidance, and interagency coordination of intelligence, gave more power to the Congressional Committee (including oversight and audit of the intelligence budget), provided for strengthened judicial control of intrusive intelligence practices (e.g., wiretapping), promoted the political neutrality of intelligence, and regulated intelligence education and training.

An ensuing decree approved a new statute for intelligence personnel, including provisions pertaining to intelligence officers' duties, rights, retribution, retirement, and disciplinary practices. Important to intelligence transparency have been the initiatives - materialized in a series of presidential decrees or changes in the intelligence agencies - of Presidents Nestor Kirchner and Cristina Fernández de Kirchner. These changes included the protection of classified information and declassification of information, on the actions of the Armed Forces; and the transfer of the National Aeronautical Police, previously under the Air Force, to the Ministry of Interior, which was renamed Airport Security Police (PSA).

Although these developments have neither settled the ongoing debate over centralizing versus decentralizing intelligence, nor have they immediately heralded more effective control and oversight, they are an important step in intelligence reform, as has been the appointment of civilians as heads of Argentina's intelligence agencies. 
Peru

Peru reestablished democracy in the early 2000s, after the dictatorship of Alberto Fujimori, and the ruthlessly effective support provided by the Servicio Inteligencia Nacional (SIN), especially under Vladimiro Montesino (1990-2000). Intelligence reform started with SIN's abolishment by President Fujimori in October 2000 through the promulgation of Law No. 27,351 of 2000, pursuant to the disclosure of a video revealing evidence of Montesinos's involvement in various acts of corruption. Since then, Peru has strived to reform and democratize its intelligence agencies in parallel with police and defense reform. Currently, Peru's National Intelligence System (SINA) coordinates the following agencies: the National Intelligence Council (COIN), the National Directorate for Intelligence (DINI), Intelligence Agencies of the Defense and Interior sectors, and the General Directorate for Security and Defense Affairs of the Ministry of Foreign Affairs. These agencies are both civilian and military, and conduct domestic and foreign intelligence.

The current intelligence system is the creation of decisionmakers within the executive and the legislative branches of government. Over the years, policymakers have faced numerous interconnected challenges, which they have only partially surmounted. One was their lack of expertise and knowledge vis-à-vis intelligence and its reform. Although they created new agencies, they failed to develop a robust legal basis for them. Even if the laws enacted in the early 2000 s provided new roles, missions, and interagency coordination for intelligence, they failed to provide for effective legislative control and oversight. ${ }^{28}$ A first attempt toward transparency was President Valentin Paniagua Corazao's (2000-2001) decision to create the Commission on Truth and Reconciliation (CVR) in 2001. Its role was to investigate, among others, crimes and human rights abuses by state agencies during the internal armed conflict (1980-2000) and the Fujimori regime, and provide recommendations to the successor system's functioning.

While the first CVR report, made public in 2003, called for the implementation of democratic civilian control of the military intelligence services, and emphasized the need for a legal framework while strengthening COIN'S role as the highest body of the intelligence system, it was not until 2006, when the law came into force that Peru's intelligence was brought under control. In addition, the leadership's lack of expertise and inability to deal with reform were reflected in poor decisions on firing former SIN personnel or high-level security appointments. Although rooting out SIN personnel, especially those involved in human rights abuses, was necessary as proof of a move away from the past, and although civilians embarked upon a purge of intelligence analysts and 
agents in the early 2000s, they failed to take into account the prospects of recruitment, education, and training of new personnel to fill the resulting vacuum of intelligence expertise. ${ }^{29}$ They even deactivated existing education and training institutions, such as SINA's strategic intelligence course, that could have contributed to an increase of expertise. The appointment in 2004 of retired military officers to key positions within the intelligence system halted the brief effort to establish civilian control. And when civilian experts from academia and NGOs were appointed heads of the intelligence system, their impact on reform was minimal. In addition, the Peruvian media revealed various scandals pertaining to illegal wiretappings, the leaking and "selling" of classified intelligence reports, and espionage, even after the passing of a law which provided for enhanced intelligence management and control, thereby reflecting the decisionmakers' inability to handle reform.

The lack of a robust legal framework and control and oversight mechanisms, coupled with the legacy of the past-including retention of many SIN agents, who continued their nondemocratic modus operandi, instability in the COIN leadership, and politicization-negatively impacted reform. The SIN's successor, COIN, is far from being a modern and professional agency in the service of democracy. As a corrective, in 2004 then-President Alejandro Toledo created a Special Commission for restructuring COIN. It assessed the progress in, and impediments to, intelligence reform up to that year, and provided recommendations for an effective trade-off between transparency, in particular establishment of democratic control and oversight mechanisms, including control and oversight of the budget, and effectiveness, in particular strengthening interagency coordination. In line with the Commission's recommendations, Congress adopted a law in 2005, enacted in early 2006, which, together with additional decrees in 2006 and 2007, established a new structure for the National Intelligence System (SINA), and new personnel regulations for intelligence agencies. Although SINA comprises all institutions engaged in intelligence, COIN is responsible for coordinating intelligence and counterintelligence activities. It reviews and sanctions the annual intelligence plan, and forwards its recommendations to the Council of National Security for adoption, as well as approves interagency coordination and cooperation doctrine, criteria, and procedures. The 2005 law established a Congressional Intelligence Committee, which has the authority to obtain classified and unclassified information from any of SINA's components, to investigate agencies ex officio, to supervise the annual plan of intelligence and its derived policies, and to request an annual secret report from the DINI. Yet the law neither stipulates control of intelligence budget, although the Comptroller General of the Republic is authorized to control special resources by the DINI Director, nor controls 
military intelligence, even if, admittedly, it is involved in the overall oversight of SINA. The law also stipulates judicial review and procedures regarding intelligence declassification. Yet, the law has several flaws as concerns intelligence transparency: it does not prevent the appointment of either active duty or retired military officers to key positions in the SIDE, whose reluctance to change is a setback to democratic civilian control; and it does not prevent the domestic collection of information on social and political organizations and movements. To deal with these challenges, the Congressional Committee in 2007 issued a secret report criticizing the performance of the agencies. Then, in 2009, the Committee developed a draft law to amend the 2006 law, which is pending approval.

Thus, although Peru's decisionmakers, including members of Congress, have shown interest in intelligence reform, including civilian democratic control, transparency, and effectiveness, their efforts have yet to be fully implemented.

\section{Poland}

Poland enjoyed a peaceful transition to democracy in 1989. Since then, policymakers within the executive - the Prime Minister, leaders of the Armed Forces, and others - and legislative branches of government have channeled their efforts toward creating a functional intelligence community. A series of reform initiatives, such as reorganizing old intelligence agencies, downsizing personnel, assigning new roles and missions, has led to Poland's current IC, consisting of five agencies: the Agency for Internal Security (ABW) and the Foreign Intelligence Agency (AW), created in 2002, replacing the Office for State Protection (UOP), the successor to Poland's Communist security service (SB); the Central Anticorruption Bureau (CBA), created in 2006; the Military Intelligence Service (SWW) and the Military Counterintelligence Service (SKW), created in 2006, replacing the Wojskowe Sluzby Informacyjne (Military Information Services-WSI). In compliance with the legal framework which comprises laws and regulations on the organization and functioning of these agencies, as well as on the protection of classified information, these organizations are military and civilian, conduct domestic and foreign intelligence, including military and defense, and have human intelligence (HUMINT), signals intelligence (SIGINT), and imagery intelligence (IMINT) capabilities.

The decisionmakers have placed the agencies under executive branch control and guidance. The Prime Minister directs and coordinates the activities of the ABW, AW, and CBA, while the Minister of Defense directs the SWW and SKW. But both the Prime Minister and the President receive SWW and SKW annual intelligence guidelines and 
end-of-year reports. A Board for Secret Services, equivalent to the U.S. National Security Council, comprising the Prime Minister as its head, the Ministers of Defense, Interior, Foreign Affairs, and Finance, the Head of National Security Bureau, the Heads of intelligence agencies, and the Head of the National Defense Commission in the first Parliament's Chamber [Sejm], as well as one Secretary, was created to foster the coordination of all the agencies. In 2005, the Polish authorities established yet another interagency coordination body: the Office of the Minister-Coordinator for Security Services. Not only does it seem to duplicate the roles and responsibilities of the other agencies, but it lacks a clear legal basis, thereby casting doubt on its lawfulness. The decisionmakers also established legislative control and oversight by creating a Special Parliamentary Committee for Secret Services within the Sejm.

Notwithstanding these developments, the pace of intelligence reform has been rather slow, and hampered by several challenges, including the decisionmakers' lack of interest and knowledge, and the legacy of the past. In this context, while decisionmakers drew attention, and channeled their efforts, to the need for downsizing legacy personnel and launched debates as early as 1990 on the need to abolish the agencies created on the ruins of the former nondemocratic secret services, not until 2002 were the new agencies created and the legal framework implemented. Yet, once Poland expressed its willingness to join the North Atlantic Treaty Organization (NATO) and the European Union (EU), the two organizations' accession requirements and-after Poland's integration into NATO in 1999 and the EU in 2004 - their membership responsibilities forced the policymakers to reshape the Polish security system, including intelligence services. Thus, the external incentive for Poland's decisionmakers to overcome the challenges of reform and balance intelligence effectiveness with transparency has brought significant changes in the country's intelligence structures, roles, missions, legal bases, and accountability mechanisms.

First came the signing of various documents, understandings, and partnerships which established NATO/EU pre-accession responsibilities for Poland. Among them were the Association Treaty with the European Community in 1991, the adoption of a National Strategy of Integration (NSI) in 1997, the Partership for Peace (PfP) framework document in 1994, and the Act on Protection of Classified Information in 1999. These elicited major changes in the activities and organization of the Polish security services, including interagency and international cooperation. The adoption of the National Security Strategy in 2000, prepared according to NATO standards, gave the intelligence agencies new responsibilities, namely to support Poland's strategic goals. The abolishment of the UOP in 2002 and the enactment of new laws on establishing the previously 
mentioned five agencies marked an opening toward effectiveness and transparency of Poland's intelligence agencies.

Notable, too, was the initiative of several policymakers to review the nation's intelligence activity. In 2004-2005, members of the Polish Supreme Chamber of Control (NIK), a constitutional body under the Sejm that monitors public and private institutions, issued reports and made surprise visits to intelligence agencies to assess their transparency and effectiveness, as well as the existing control and oversight mechanisms. The NIK report found flaws in the legal framework for intelligence, including the delineation of roles and missions, as well as in the effectiveness and appropriateness $^{30}$ of democratic control and oversight mechanisms. ThenPresident Lech Kaczyński demonstrated interest in intelligence transparency by declassifying and making public a report issued by the UOP's abolisher, Antoni Macierewicz, in 2007. This was the first time that information on WSI activity had been made public.

\section{Romania $^{31}$}

Romania embarked upon democratization in December 1989 after the collapse of the Nicolae Ceauşescu regime, one of the most atrocious Communist dictatorships in Central and Eastern Europe. The Communist intelligence apparatus - the nefarious Securitate-was dismantled immediately after the regime's fall and placed indefinitely under the jurisdiction of the military. Nevertheless, specific ethnic clashes led to the creation of at least nine new agencies in March 1990. These agencies preserved much of the infrastructure, logistics, personnel, and files of the former Communist institution. Since then, Romania has endeavored to reach a balance between effectiveness and transparency in the post-Communist intelligence agencies. While the pursuit of transparency was obvious, considering the Securitate's atrocities during the Ceauşescu regime, the focus on effectiveness can be explained by the decisionmakers' awareness of various threats to Romania's security, emanating from its dangerous geographic surroundings, dominated by failed states and conflicts, and such transnational threats as organized crime, terrorism, and the proliferation of weapons of mass destruction. After a series of reorganizations, the decisionmakers decreased the number of agencies from nine to six by 2005: independent - the Romanian Intelligence Service (SRI); the Foreign Intelligence Service (SIE); the Guard and Protection Service (SPP), and the Special Telecommunication Service (STS); and ministerial-the General Directorate for Intelligence and Internal Protection (DGIPI) and the Directorate for General Information of the Army (DGIA). The executive branch, which includes the President, the National Defense Supreme Council (CSAT) coordinates all intelligence and 
security activities and agencies. A National Intelligence Community (CNI) was created by the CSAT in 2005 to ease information and intelligence sharing among all agencies, as well as the dissemination of relevant materials to consumers. The decisionmakers have also progressively developed a rich legal framework for intelligence, consisting of numerous laws and regulations on the organization and functioning of the agencies, interagency coordination, and protection of classified information, as well as access to intelligence information and declassification. The various agencies now conduct domestic, foreign, military, and police/law enforcement intelligence in compliance with the legislation. They operate under the mandate of the executive (through the President, Prime Minister, and CSAT), legislative (through two permanent Committees in the two chambers of the Parliament, two select committees, ad hoc committees, and the Court of Audit), and are reviewed by the Judicial branch (through the Constitutional Court and judges), as well as other mechanisms (such as the Ombudsman).

Romania is an important case study of the role of policymakers in intelligence reform, for at least two reasons. First, although policymakers of the executive and legislative branches of the government have contributed to the creation and development of the post-Communist intelligence community, and although they sought to develop both transparent and effective intelligence agencies, they cannot be entirely credited for the progress of the reform. Rather, it was the "carrots and sticks" approach of NATO and EU membership requirements-two organizations which Romania very much desired to join-as well as a vigilant media that motivated, stimulated, and/or compelled the Romanian decisionmakers to reform intelligence.

During the first years of transition, the policymakers lacked knowledge on intelligence reform, as reflected in many gaps in the legal framework for intelligence, as well in their inability to perform effective intelligence oversight, which allowed for IC transgressions and misbehavior. They also had to deal with the agencies' legacy of the past and their resistance to reform, reflected in the perpetuation of former non-democratic personnel in the newly created agencies, many in important positions, which continued unlawful political police and politicization practices and blackmail. In addition, the policymakers also had to implement other competing reform priorities, for example, creating a new Constitution and developing a political class. They also encountered endemic corruption, with Romania being one of the most corrupt countries in the world. But the unanimous desire to join NATO/EU helped them overcome these challenges. The policymakers acquired expertise in intelligence through access to intelligence literature, education, training with IC personnel, and from NGOs, media, foreign experts, foreign visits, and experience sharing. They dealt with the 
legacy of the past and resistance to reform by vetting and removing Securitate personnel, hiring new people who were not involved with Securitate, investing in the professionalization of intelligence personnel, generally making intelligence reform a priority. Besides the decisionmakers' interest in joining NATO and the EU, the media exposed scandals and irregularities regarding intelligence reform that forced the policymakers to deal with these challenges. Yet as Marius Oprea pointed out, after 1989, the new political power had no intention to engage in open war against the Securitate, and any "war" was played out exclusively in the media. ${ }^{32}$

Corruption, still high in Romania, remains a drawback. And the lack of "carrots and sticks" has, since Romania's integration in NATO and EU, led to a decreased interest on the part of policymakers, especially those in the legislative branch, to continue democratic reform, particularly in exercising proper oversight. Oddly, the legacy of the past is minimal, and the lack of expertise, after twenty years of democracy and access to a rich literature on intelligence, is not an issue. In fact, many civilian decisionmakers and intelligence professionals are graduates of various security courses. What hinders modernization and reform is a lack of interest-a "hands-off" attitude toward intelligence and intelligence reform, especially with regard to improving the legal framework for intelligence. Although the decisionmakers have progressively developed a rich legal framework, it has serious lacunae. As a corrective, the executive proposed a package of five national security related laws back in 2005-2006, which, although undergoing several changes after open debates, remains in the Parliament. Instead, political infighting and bad economy are current preoccupations for parliamentarians.

The executive branch has been more supportive of broader reforms as a means of raising public interest in intelligence and institutionalizing the processes that support transparency and effectiveness. The government has initiated debates and meetings on security and intelligence matters, among them a discussion of the role of intelligence in a democratic society, and a review of current national, regional, and global security threats. Decisionmakers and intelligence professionals have jointly sought to enrich Romania's intelligence literature by publishing various books and articles on intelligence and democracy with the goal of familiarizing Romanian society with the concepts of "intelligence" versus "information," and by declassifying and publishing information on Romania's prior intelligence agencies. The decisionmakers have also invested in professionalization by implementing better standards for recruitment, in parallel with Securitate personnel removal and promotion of new personnel; continuous education and training programs for intelligence personnel, including ethics, human rights, transparency, and accountability; issuing security clearances to permit access to classified information; and nurturing a responsibility for 
democracy. The CSAT has supported the SRI's modernization program, "Strategic Vision 2007-2010," aimed at comprehensive debureaucratization and an improved intelligence cycle, from decisionmakers to intelligence officers and back.

Despite all these challenges, and bolstered by contemporary management, Romania's intelligence agencies continue to be effective, both domestically and internationally, as acknowledged by not only foreign partners and allies, but also the general public. Nevertheless, formal legislative oversight processes need to be improved, while the media's informal oversight should continue even if often being sensationalist and profit-driven, in order to prevent the agencies' accumulation of too much power, especially given the shakiness of today's political and economic situation.

\section{Spain}

Spain peacefully transitioned to democracy in 1975, following the death of General Francisco Franco. Since then, civilians in Spain, especially from the executive branch, have endeavored to develop democratic intelligence agencies that are both effective and under control.

Ever since the transition to democracy, policymakers have viewed terrorism as the primary security challenge for Spain. From this perspective, and later, from the perspective of EU and NATO membership (1986), they deemed it necessary to develop an intelligence system in the service of democracy. Intelligence reform in Spain started in 1977, when Vice President Gutiérrez Mellado set up Superior Defense Information (CESID) by merging all intelligence agencies inherited from Franco, and placed it under the Ministry of Defense. The CESID was replaced in 2001 by the National Intelligence Center (CNI), which also operates within the Ministry of Defense. The CNI, Spain's current intelligence agency, ${ }^{33}$ does both domestic and foreign, including military, intelligence. Its products are disseminated to the Presidency, which is the main user and also the authority that decides on the recipients of intelligence, as well as to the Ministry of Foreign Affairs and Cooperation, the Ministry of Defense, the Ministry of Economy and Finance, and the Ministry of Interior. Democratic control of intelligence is carried out by the executive, the legislative (through the Defense Committee of the Congress of Deputies), and judicial (through the Supreme Court) branches. The rather secretive Spanish security system is based on a 1968 law, which continues to regulate access to official secrets.

Notwithstanding the policymakers' interest in intelligence reform as part of a wider objective-bringing the military under democratic control to prevent a return to the past - balancing effectiveness with transparency in Spain has been less than perfect. Policymakers have encountered several 
challenges and obstacles, some still present. As in Brazil and Romania, the first obstacle was the resistance of the intelligence agencies to reform. The CESID inherited the military and police personnel trained in the Franco years, many in key positions within the directorate. Such personnel continued their non-democratic practices, in particular, the illegal surveillance of political figures, and also sought to oppose reform. Doubts also arose over the CESID's participation in the attempted coup d'état of 23 February 1981. Another challenge has been the impossibility, based on old regulations, of declassifying materials, including those pertaining to the Franco dictatorship. Considering these impediments, it is not surprising that the public perception of intelligence in Spain remains negative even today. The stigma of the nondemocratic past is still there.

Lack of knowledge and expertise in intelligence reform, particularly with regard to the exercise of effective democratic control of intelligence, as well as political infighting, have also held back reform. For many years, executive control of the CESID involved more or less personal ties between the Minister of Defense and the director of the service, rather than a formally established control and oversight channel. In 1995, Juan Alberto Perote, head of the CESID Operations Group, was accused of leaking 1,200 documents from the agency, containing information on CESID's wiretapping of politicians, journalists, and other key public figures for blackmail. The strong media pressure following this scandal resulted in the resignation of the country's Vice President, the Minister of Defense, and the director of CESID. Another telling example is the CESID's 1998 illegal surveillance of the ETA's political wing, Herri Batasuna, which the government ignored. Also related to the limited expertise and knowledge in intelligence matters is the lack of policy-driven intelligence, specifically, the lack of requirements from policymakers, and the absence of a relationship, including feedback, between the analysts and the consumer. This lack of knowledge is mirrored in the faulty interagency coordination of all security institutions by the executive. Spain's intelligence agency is part of an amalgam of competing security bureaucracies with overlapping responsibilities, including the Ministry of Defense, Ministry of Interior, and Ministry of Foreign Affairs. Although the idea of interagency coordination has been advocated since 1976, and even tentatively materialized since mid-1980s-for anti-terrorism purposes-Spain still lacks real interagency coordination. It is not surprising, then, that Spain's intelligence has not been a major player in international deployments. The Defense Committee has also been incapable of exercising proper supervision of intelligence, in particular oversight of the budget, and particularly the use of secret money for the "dirty war" against ETA. The same applies to committees of inquiry regarding intelligence misdemeanors or failures. For example, the committee established to investigate the lethal 
terrorist attacks of 11 March 2004 in Madrid failed to reach an agreement on what caused the failure of intelligence to prevent them, let alone provide recommendations regarding intelligence activity improvement to ensure that such attacks would not happen again. Relentless political infighting and mutual blame between members of the two big parties comprising the committee, the Socialist Party and the Popular Party, led to the stalemate.

Moreover, the policymakers in charge of intelligence reform first learned of many intelligence illegalities from the press. As in Romania, the media, whether sensationalist and profit-driven or not, has stepped in as a more effective oversight mechanism than the formal structures, and acted as a catalyst for reform, change, and reprimand. A recent example is the 2009 media coverage of the CNI's misuse of public funds for personal pleasures and nepotism under the then-Director, Alberto Saiz. The case also exposed the inability of the formal control and oversight bodies to properly monitor the agency and its personnel. The media reporting ultimately led to Saiz's resignation.

The attempts of policymakers to overcome these challenges through such reforms as replacing the CESID with the CNI, enacting a law on the organization and functioning of the Center, and enforcing prior judicial approval of intrusive CNI activities by a Supreme Court magistrate have not much improved either the effectiveness or accountability of intelligence. A security and intelligence culture has sluggishly emerged, particularly after the Cold War. Since 1997, the Spanish Institute for Strategic Studies of the Ministry of Defense has developed an outreach program, which has knitted together the Armed Forces and civil society, including academia, via courses, conferences, seminars, and research initiatives. Intelligence promotion has been accomplished through the CNI's National Office for Intelligence and Counter-Intelligence. While the perception of intelligence has admittedly changed within academia, it has yet to change among Spain's citizenry.

\section{Russia}

Russia is a stunning case of democratic regress. Since the collapse of the Soviet Union in 1991, Russia has been incapable of providing basic human rights, freedoms, and liberties for its citizens. It has fallen short in permitting political freedom, and has hindered the development of a vigorous civil society able to check the government. Thus, the country cannot be considered a democracy. ${ }^{34}$ Russian's political system has instead evolved from a super-presidential republic to what scholar Ivan Krastev terms "democracy's doubles," meaning "regimes that claim to be democratic and may look like democracies, but which rule like autocracies." 35 Arguably, Russia's intelligence agencies continue to be the chief prop of the regime, in 
particular the executive, which dominates all other branches. They continue to conduct their clandestine activities against the population. Although intelligence reform has been on the Russian decisionmakers' agenda, the purpose of reform has not been the balancing of effectiveness with transparency, but rather, developing intelligence agencies that serve and are controlled by the executive, especially the Presidency.

Russia's current intelligence system is an inheritance from the Committee of State Security (KGB), which was split into several agencies, as follows:

- the External Intelligence Service (SVR) of the Russian Federation, as the successor of the First Chief Directorate of the KGB, responsible for foreign intelligence;

- the Federal Security Service (FSB), the former Ministry of Security, as the successor to the Second and Third Chief Directorates, responsible for counterintelligence and military counterintelligence, respectively;

- the Fourth Directorate, for transportation security;

- the Directorate for Protection of the Constitution;

- the Sixth Directorate, tasked with combatting economic crime and corruption;

- the Seventh Directorate, for surveillance and wiretapping;

- the Federal Agency for Government Communications and Information (FAPSI), as the successor to the Eighth Chief Directorate (communications and SIGINT);

- the Main Guard Directorate (GUO), as the successor to the Ninth Directorate, to provide the physical security of high officials;

- the Committee for Protection of Russian Borders, as the successor to the Border Guards;

- the Main Directorate for Special Projects, attached to the office of the President of the Russian Federation, as the successor to the Fifteenth Directorate, for the maintenance and protection of secure underground facilities for the leadership; and,

- the unchanged Main Intelligence Directorate of the General Staff (GRU).

In accordance with the legal framework, consisting of several laws and presidential directives, including laws on organization and functioning of intelligence agencies and ministry of defense, on fighting terrorism, on state secrets, and on national security, the various agencies conduct a wide range of domestic, foreign, military, and civilian intelligence and counterintelligence activities. They are not, however, an intelligence community. Although a Security Council does some coordination of intelligence and security activities, no formal horizontal links exist among the agencies, nor is there an equivalent of a director of national intelligence. The intelligence agencies report directly to the President, while the GRU also reports to the Minister of Defense and the Chief of General Staff. The executive branch has granted them tremendous power and insulation from external scrutiny. 
Since 1991, the intelligence agencies have been major tools and players in the political class's constant struggle for power and wealth. The 1993 Constitution, written to accommodate then-President Boris Yeltsin's political and personal interests and needs, increased the powers of the executive vis-à-vis intelligence, to the detriment of the legislative and judiciary branches. To consolidate their power, Russia's Presidents have personally appointed select intelligence personnel (siloviki) ${ }^{36}$ in various key positions within the government. Examples include Yevgeniy Primakov, a former director of the SVR (1991-1996), who was allegedly involved with the KGB, and became Prime Minister in 1999, and former KGB officer Nikolai Bordyuzha, who became head of the Presidential Administration. Many other former KGB officers were appointed to very important positions, including Deputy Minister of Foreign Affairs, Deputy Secretary of the Security Council, chief military prosecutor, and Deputy Director of the official ITAR-TASS news agency. The siloviki are an "active reserve" in that they keep their rank and salary in their original agency, and report to the agency, while operating in the civilian bureaucracy from which they get a second salary. Such reliance on siloviki made it possible for Vladimir Putin in 2008, when appointed Prime Minister, to change the balance of power from the Kremlin (the Headquarters of the President) to Moscow's White House (the Headquarters of the Prime Minister), even if President Dmitri Medvedev has also used siloviki.

Considering all these facts, that intelligence officers and their agencies opposed changes and checks and balances is not surprising. The executive did whatever it could to weaken legislative and judicial control. With regard to legislative control and oversight, the two chambers of Parliament - the Federation Council and the Duma—have been highly penetrated by individuals appointed directly by the President, or by Intelligence members of the presidential party, including former KGB/FSB and MVD personnel. While the Federation Council's Intelligence Committee deals primarily with issues of salaries and benefits for agency personnel, the Duma's committee deals with writing, adopting, and amending new legislation in line with the President's preferences and approving the budget - which is almost entirely classified even for members of parliament. No committee supervises intelligence operations. Although an Accounting Chamber, equivalent to the U.S. General Accountability Office can audit intelligence expenditures, it cannot do so with regard to operations. Another handicap for Parliament is its lack of authority to conduct investigations related to intelligence. A telling example is the investigation of the 2004 hostage taking in Ossetia. ${ }^{37}$ Although a joint committee was created with then-President Putin's approval to investigate how the agencies handled the situation, it was nothing more than a way to turn away public anger over the government's failure to stop terrorism. The committee's report, released in 2006, commended the actions by the 
central government in Moscow, while admonishing the local authorities of the Republic of North Ossetia.

Putin's administration enacted a law in 2005 which severely limits the Federal Assembly's ability to conduct inquiries on intelligence. No parliamentary inquiries have been held since the adoption of this law. With regard to judicial review, the judiciary is now part of the executive, which has brought in former intelligence personnel and implemented legislation that impedes judicial scrutiny of intelligence. Likewise, external oversight by civil society, including the media, is absent. The executive-the President as much as the intelligence agencies-actually controls, monitors, and neutralizes the activity of NGOs and the media.

The leadership's use of intelligence for personal gain and the resulting lack of supervision and oversight, have begotten corruption and a loss of professionalism by the officers of the security agencies. The FSB's domination within the government has fueled bribery, torture, and all types of abuse and misconduct. With the support of intelligence personnel, the Russian government has become one of the most corrupt in the world, ranking number 154 out of 178 on the Transparency International listing in $2010 .^{38}$ Under these circumstances, even the effectiveness of intelligence is questioned. On the one hand, Russia's external intelligence service has proven its effectiveness on several occasions, including its penetration of the Central Intelligence Agency (CIA) and Federal Bureau of Investigation (FBI) in the 1990s, its correct estimates of the threat from Afghanistan's Taliban movement, and its 2002 estimates that Saudi Arabia and Pakistan rather than Iraq were the centers of gravity in the Global War on Terror. On the other hand, other examples, such as its failure to predict the outcome of Yugoslavia's 2000 elections which cost Slobodan Milosevic his job, its alleged prediction of a prolonged conventional conflict, and the apparent ineffectiveness of Russian illegal operatives arrested in the United States in June 2010 have cast doubt about their capabilities.

\section{ANALYZING THE CASE STUDIES}

Based on our survey of seven countries, six of which have undertaken a democratic reform of intelligence, the following key points vis-à-vis policymakers' contribution to intelligence reform are evident.

At a minimum, intelligence reform requires political will and interest on their part. The incentive to reform intelligence can include:

1. external, e.g., carrots and sticks from NATO and the EU as in Romania, Poland, and, somewhat less, Spain;

2. prestige, e.g., Romania, and Brazil in international peace operations; 
3. direct interest in one component of the reform - transparency or effectivenessfor rational grounds, e.g., punish nondemocratic regime abuses and prevent the return of those practices in the new democracy, or awareness of threats;

4. a crisis or failure; or

5. a combination of some or all of these.

To prevent a return to the past, policymakers in six of the seven countriesRussia excluded, as they do not pursue democratic consolidation-have primarily sought to bring intelligence under control and, hence, increase the transparency dimension of intelligence reform. In four of these countries (Romania, Poland, Spain, and later Brazil), policymakers have also sought intelligence effectiveness, motivated by

1. external incentives (Romania, Poland, Spain),

2. awareness of threats (Romania, Poland, Peru, and more recently, Brazil),

3. prestige (Romania, Poland, Brazil), and

4. crises (Romania, Spain).

Of the six countries seeking IC control, only in Romania, Poland, and perhaps Spain has democratic control also contributed to intelligence effectiveness, yet probably still from the perspective of external drive that influenced decisionmakers. Those countries that had an external drive and incentive for reform have been more successful than the others in terms of reform. Nevertheless, when the external push disappears, reform tends to atrophy or stagnate, as it did in Romania. Intelligence reform is, therefore, not a linear process, while past experience is no guarantee of continued success.

But interest alone does not ensure effective reform. The case of Peru has shown that policymakers have been interested in intelligence reform, due to the legacy of the past and ongoing security challenges, but reform has so far been ineffective, which leads to the second issue: expertise. In most of the countries examined here, at least at the beginning of transition, policymakers lacked knowledge on how to deal with intelligence. We also found that reform initiatives tend to disappear with a change of government - as in Romania and Brazil, in which the leaders with the political will are replaced by others lacking it, or with the lack of external incentives (e.g., Romania). From the four case studies of nations that were, or had been, military dictatorships (Spain, Brazil, Argentina, and Peru), we saw that the decisionmakers' main focus was to increase transparency and accountability. Where too much focus was placed on developing democratic control and accountability, security was negatively affected, hence, policymaking has also suffered, as in Argentina. And, where reform, especially to increase effectiveness, has been pursued after a crisis, 
it was far from successful (Argentina and Spain). Policymakers have therefore had more difficulty dealing with military intelligence in seeking to balance effectiveness with transparency.

For countries that achieved some success in either transparency or effectiveness, or both, in intelligence, time is very important. Even in long-established democracies, having intelligence agencies that are both effective and accountable does not occur overnight. The same applies to emerging democracies, but more so.

Although corruption and the misuse by decisionmakers of intelligence personnel and budget for personal and political reasons have been encountered in all countries, only Russia embodies these problems on a regular basis. That can be explained by the overall lack of interest in democratization of the country.

This article analyzes the potential contribution of policymakers to the democratic reform of intelligence and draws from the experience of seven developing democracies (Brazil, Argentina, Peru, Poland, Romania, and Spain) and Russia. Our research has indicated that, although democratic reform of intelligence is not always an urgent or appealing objective, it is not ultimately an impossible job for policymakers.

All six countries that attempted to democratize intelligence were not able to easily overcome the past. For many years, they had to fight many challenges. Nevertheless, in at least four of them-Poland, Brazil, Romania, and Spain - the decisionmakers have managed to institutionalize agencies that are either transparent or effective, or both.

Our study of democratic security, including intelligence, institutionbuilding suggests that civilian policymakers are the key players in the intelligence process and reform.

\section{REFERENCES}

1 “Intelligence Practice and Democratic Oversight. A Practitioner's View," Occasional Paper No. 3, Geneva Centre for the Democratic Control of Armed Forces (DCAF), July 2003, http://www.dcaf.ch/publications/Occasional_ Papers/3.pdf, p. 75.

${ }^{2}$ All countries were dictatorships in which the intelligence agencies were the chief props of the authoritarian leaders. We understand that assessing intelligence democratization is problematic, due mainly to the cloistered nature of intelligence bureaucracies. Nevertheless, access to the existing intelligence literature, but mainly through involvement in the programs conducted by the Center for Civil-Military Relations (CCMR) for foreign military and civilian partners, enabled us to discuss intelligence reform with intelligence representatives from new democracies. We, are confident that we have useful insights on the topic, at least in Brazil, Argentina, Peru, and 
Romania (which we visited several times). Both of us speak the languages of Peru and Argentina. We both speak the languages of either Brazil or Romania. In addition, we have relied heavily on the empirical research of our colleagues in four specific case studies. The research team includes Misha Tsypkin, an Associate Professor at the NSA, and expert or Russia; Eduardo Estevez, Director of the Fundación de Estudios Económicos y Políticas Públicas in Argentina, an expert on intelligence reform in Latin America; Karina Marczuk, professor at the Institute of Political Science, University of Warsaw, Poland, an expert on democratic consolidation in Eastern Europe; Joanisval Brito Gonçalves, Senior Consultant on Foreign Affairs and Defense at the Senate of Brazil and advisor on intelligence for the Brazilian Joint Committee on Intelligence Oversight; and Antonio M. Díaz Fernández, professor at University of Burgos. Their papers were part of the NS3155 course curriculum, during summer 2010, which both authors taught.

3 "Intelligence and Policy-Making: A Bibliography" compiled by Greta E. Marlatt, January 2011, available at http://www.nps.edu/Library/Research/ Bibliographies/Intelligence/IntellPolicyBib.html

${ }^{4}$ Especially during periods when national security does not encounter imminent threats (e.g., the post-Cold War period), instead of investing in intelligence, decisionmakers prefer to cut budgets or shelve any initiatives to improve effectiveness (e.g., improve collection or analysis). Unfortunately, if a crisis occurs, hasty attempts to redress intelligence are seldom successful. Timothy J. Doorey, "Intelligence Secrecy and Transparency: Finding the Proper Balance from the War of Independence to the War on Terror," Strategic Insights, Vol. VI, Issue 3, May 2007.

5 Although there is no agreed definition of intelligence, Mark M. Lowenthal provides the most comprehensive one. Mark M. Lowenthal, Intelligence: From Secrets to Policy (Washington, DC: CQ Press, 2008), pp. 1-9.

${ }^{6}$ Loch K. Johnson, Secret Agencies: U.S. Intelligence in a Hostile World (New Haven, CT: Yale University Press, 1996), p. 119.

${ }^{7}$ Robert Kennedy, Of Knowledge and Power: The Complexities of National Intelligence (Westport, CT: Praeger Security International, 2008), pp. ix-xiii.

8 The involvement of decisionmakers led to success in averting the Millennium attacks, while the lack of involvement in the summer of 2001 led to failure on 11 September 2001. See Sandy Berger, in Amy B. Zegart, Spying Blind: The CIA, the FBI, and the Origins of 9/11 (Princeton, NJ: Princeton University Press, 2007), pp. 1-14.

9 Robert Kennedy, Of Knowledge and Power: The Complexities of National Intelligence, pp. 51-76.

10 Mireille Radoi, Serviciile de Informatii si Decizia Politica (Bucuresti: Tritonic, 2005), pp. 7-190.

11 Mihaela Matei, "Îmbunatatirea cooperarii între producatorii si consumatorii de intelligence," Intelligence, Year 5, No. 13, December 2008, pp. 37. 
12 Jennifer E. Sims, "Understanding Friends and Enemies. The Context for American Intelligence Reform," in Jennifer E. Sims and Burton Gerber, eds., "Introduction," Transforming U.S. Intelligence (Washington, DC: Georgetown University Press, 2005), pp. 14-31.

13 "Intelligence Practice and Democratic Oversight. A Practitioner's View," Occasional Paper No. 3, pp. 1-75; Robert Kennedy, Of Knowledge and Power: The Complexities of National Intelligence, pp. 7-26.

14 "Intelligence Services and Democracy," Geneva Centre for the Democratic Control of Armed Forces (DCAF), Working Paper Series, No. 13, Geneva, April 2002.

15 Deborah G. Barger, "Toward a Revolution Intelligence Affairs," RAND Corporation, 2005, p. 13.

16 Melissa Boyle Mahle: Denial and Deception: An Insider's View of the CIA from Iran-Contra to 9/11 (New York: Nation Books, 2004), pp. 47.

${ }^{17}$ Except former Czechoslovakia, which completely removed the former intelligence apparatus. Larry L. Watts, "Intelligence Reform in Europe's Emerging Democracies," pp. 11-25.

18 Mark M. Lowenthal, Intelligence: From Secrets to Policy, pp. 1-10; and Richard K. Betts, Enemies of Intelligence: Knowledge and Power in American National Security (New York: Columbia University Press, 2007), pp. 1-18.

19 The discussion is based on personal views of the two authors, as well as the following works: Matei and Bruneau Democratization; Edmunds; Bruneau Civilian Control, Bruneau and Matei, Democratization old; Bruneau and Matei Oxford; "Intelligence Practice and Democratic Oversight. A Practitioner's View," Occasional Paper No. 3, Geneva Centre for the Democratic Control of Armed Forces (DCAF), July 2003, http://www.dcaf.ch/publications / Occasional_Papers/3.pdf, pp. 1-75; Congress as a Consumer of Intelligence Information, Alfred Cumming, 28 January, 2010, Congressional Research Service, 7-5700, www.crs.gov R40136, pp. 1-11; Gregory F. Treverton and Wilhelm Agrell, "Introduction," in Gregory F. Treverton and Wilhelm Agrell, eds., National Intelligence Systems: Current Research and Future Prospects (New York: Cambridge University Press, 2009), pp. 1-10; and Gregory F. Treverton, Intelligence for an Age of Terror (New York: Cambridge University Press, 2009), pp. 1-306.

20 "Intelligence Practice and Democratic Oversight. A Practitioner's View," Occasional Paper No. 3, pp. 1-75.

21 Robert Jervis, "The Politics and Psychology of Intelligence and Intelligence Reform," in James P. Pfiffner and Mark Phythian, eds., Intelligence and National Security Policymaking on Iraq. British and American Perspectives (Manchester, UK: United Press, 2008), p. 163.

22 It is difficult to find acknowledged successes in the field of intelligence; studies on intelligence failures, misperception, military misfortunes are, however, common. A possible exception is the very telling memoir of the head of Israeli civilian intelligence. See Efraim Halevy, Man in the Shadows: Inside the Middle East Crisis with a Man Who Led the Mossad (New York: St. Martin's Press, 2006). 
23 In each country the following questions oriented the research: 1. Has the new democracy developed new intelligence institutions or reformed the old ones? 2. If yes, how many intelligence agencies does it currently have and what type of intelligence do they involve? 3. Who are the decisionmakers in intelligence and security? 4. Have decisionmakers contributed to democratic intelligence reform? 4.a. If yes, what was the driving force? 4.b. If yes, how have they contributed to intelligence reform? 4.c. Did they encounter any challenges and if so, how have they (if at all) overcome them? We asked the experts we commissioned to write papers to respond to these questions.

24 A civilian federal agency, with no law enforcement powers, with focus on security intelligence but also responsible for foreign intelligence.

25 The Law grants ABIN the role of interagency coordinator, yet an Executive Decree (n. 3,376/2002) grants this authority to GSI.

${ }^{26}$ Unfortunately, progress has been stymied as he lost his seat, as did the other more active members of Congress. As noted before, engagement in intelligence does not bring in many votes.

27 All these initiatives were on hold as the new administration, which took office on 1 January 2011, sorted through its priorities.

28 Although an interim Committee was created in the Parliament, an actual Oversight Committee was not set up until 2006-2007.

29 A notable fact is that after the dissolution of the SIN, and unlike the CNI and its successors, the DIGIMIN retained its qualified and experienced personnel, which allowed the service since then to maintain a high operational capacity.

${ }^{30}$ Lack of control by appropriate bodies of the Chancellery of the Prime Minister and the Ministry of Defense, and oral orders issued by the Prime Minister instead of written.

31 The research for this section was conducted in Romania by both authors between 2009-2010. Also, see Florina Cristiana (Cris) Matei, "The Legal Framework for Intelligence in Post-Communist Romania," International Journal of Intelligence and CounterIntelligence, Vol. 4, No. 22, Winter 2009-2010, pp. 667-698, 2009; Florina Cristiana Matei, "Challenges of Intelligence Sharing in Romania," Intelligence and National Security, Vol. 24, No. 4, August 2009, pp. 574-585; George Cristian Maior, ed., Un Razboi al Mintii. Intelligence, servicii de informatii si cunoastere strategica in secolul XXI (Bucuresti, RAO, 2010); Dan Dimancescu, ed., Romania Redux. A View from Harvard (Bucuresti: Humanitas, 2004); Marius Oprea, Mostenitorii Securitatii (Bucuresti: Humanitas 2004), p. 25; Tom Gallagher, Furtul Unei Natiuni: Romania de la Communism Incoace (Bucuresti: Humanitas 2004); Intelligence Journal, www.sri.ro Infosfera Journal, www.mapn.ro

32 Marius Oprea, Mostenitorii Securitatii, p. 38.

33 However entities within the Ministry of Interior and Ministry of Foreign Affairs also perform intelligence functions.

${ }^{34}$ Larry Diamond, The Spirit of Democracy (New York: Times Books, 2008), p. 22. 
35 Ivan Krastev, "Democracy’s 'Doubles,'” Journal of Democracy, Vol. 17, No. 2, April 2006, p. 52.

36 Siloviki - those representing the agencies that use force - a term to describe those working for intelligence services and the military.

37 The terrorists (mostly Chechens) took over a thousand hostages in a school in Beslan, North Ossetia. A chaotic storming of the school killed 331 children and adults, which frightened and angered the public and the political elite.

38 "Corruption Index 2010 from Transparency International: Find Out How Each Country Compares," available at http://www.guardian.co.uk/news/datablog/ 2010/oct/26/corruption-index-2010-transparency-international 